\title{
Alterations in net glucose uptake and in the pancreatic B-cell GLUT2 transporter induced by diazoxide and by secretory stimuli
}

\author{
L Zhao, Z Li, M Kullin, L A H Borg ${ }^{\mathbf{1}}$ and F A Karlsson \\ Department of Medical Sciences, University Hospital, SE-751 85 Uppsala, Sweden \\ ${ }^{1}$ Department of Medical Cell Biology, University of Uppsala, PO Box 571, SE-751 23 Uppsala, Sweden \\ (Requests for offprints should be addressed to L A H Borg; Email: Hakan.Borg@medcellbiol.uu.se)
}

\begin{abstract}
The pancreatic B-cell GLUT2 transporter and glucose metabolism were examined in isolated rat islets subjected to treatments affecting insulin secretion. Diazoxide was used to inhibit, while glipizide or depolarization of the plasma membrane with a high extracellular $\mathrm{K}^{+}$concentration were used to stimulate insulin release in short-term experiments. Islet GLUT2 and insulin were determined by quantitative immunohistochemistry and GLUT2 was also determined by Western blot analysis. Islet net glucose uptake and glucose oxidation were measured using radioactively labelled glucose. Exposure of the islets to diazoxide was associated with a marked increase in the B-cell plasma membrane staining for GLUT2 and increased net glucose uptake. Glucose oxidation was not changed,
\end{abstract}

which may reflect a lowered energy requirement. Conversely, islets subjected to a stimulated insulin secretion with glipizide or a high extracellular $\mathrm{K}^{+}$concentration showed a reduced staining of the GLUT2 transporter. The net glucose uptake and glucose oxidation were also reduced. In islets exposed to the high $\mathrm{K}^{+}$concentration no change in the molecular weight or phosphorylation of GLUT2 was observed but a lesser amount of the transporter was found by Western blot analysis. Thus, GLUT2 and glucose uptake in the pancreatic B-cell are modified by the secretory process, which suggests that changes in the glucose transporter have a functional role in normal B-cell physiology.

Journal of Endocrinology (2005) 185, 291-299

\section{Introduction}

The metabolic and secretory activities of the pancreatic B-cells are of importance for their susceptibility to damage. Chronic hyperglycaemia can have a glucotoxic effect and impair B-cell function and survival (Yki-Järvinen 1992). High glucose concentrations in vitro also sensitize the B-cells to direct damage by diabetogenic agents such as streptozotocin (Eizirik et al. 1988) and cytokines such as interleukin-1 (Palmer et al. 1989). B-cell secretory rest (Karlsson \& Björk 1997) induced by prophylactic insulin treatment can, on the other hand, delay or prevent the onset of autoimmune diabetes in experimental models such as the NOD mouse (Atkinson et al. 1990) and the BB rat (Gotfredsen et al. 1985). In humans, insulin treatment at the clinical onset of type I diabetes commonly improves B-cell function. The remission of the disease may reflect B-cell recovery from glucotoxic effects or reduced immune-mediated impairments. We and others have shown that the ambient glucose concentration regulates islet cell auto-antigen expression (Kämpe et al. 1989, Hagopian et al. 1993) and that this expression is linked to insulin secretion per se (Björk et al. 1992). Therefore, a normalization of blood glucose brought about by insulin therapy may lead to reduced destruction of the pancreatic B-cells. Indeed, B-cell secretory rest has been induced with promising results in a trial in which 3 months of supplementary treatment with diazoxide, which is an inhibitor of insulin release, was given to patients with newly onset type I diabetes (Björk et al.1996). Treatment with diazoxide has also been reported to prolong improvement of B-cell function in rat islets transplanted to a diabetic environment (Hiramatsu et al. 2000). Altogether, these observations indicate that the sensitivity of the $\mathrm{B}$-cells to destruction is dependent upon their functional activity and seems to be linked to the process of glucose-stimulated insulin release.

Insulin secretion is stimulated by a sequence of events in which glucose is metabolized by the pancreatic B-cell to generate an increase in ATP, followed by closure of ATP-dependent $\mathrm{K}^{+}$channels and subsequent depolarization of the B-cell plasma membrane. This leads to the opening of voltage-dependent $\mathrm{Ca}^{2+}$ channels, an increase in cytosolic $\mathrm{Ca}^{2+}$ concentration and reactions terminating with the exocytosis of insulin-containing secretory granules. Diazoxide inhibits insulin secretion by opening ATP-dependent $\mathrm{K}^{+}$channels and hyperpolarizing the B-cell plasma membrane. We have found that diazoxide 
and another opener of ATP-dependent $\mathrm{K}^{+}$channels, NNC-0118, protect rat islets against streptozotocin damage (Kullin et al. 2000). Streptozotocin is a well-known experimental B-cell toxin (Kolb 1987). It contains a glucose moiety and is taken up into the B-cells by the low affinity transporter GLUT2. The transporter is thus needed for streptozotocin toxicity. Cells lacking GLUT2 are, dose-dependently, rendered sensitive to the toxin by transgenic expression of the transporter (Schnedl et al. 1994).

Although diazoxide has been reported not to alter islet oxidation of glucose (Ashcroft \& Randle 1970, Bergsten et al. 1988, Malaisse et al. 1999), the beneficial effect of B-cell rest caused by this drug at exposure to streptozotocin or under other diabetogenic conditions might involve changes in GLUT2 function. Therefore, we studied the effects of diazoxide on GLUT2 in isolated rat islets. To do this, confocal microscopy and quantitative immunohistochemistry were used in conjunction with measurements of islet net uptake of glucose and glucose oxidation. For comparison, we also examined the effects of stimulated insulin release on GLUT2 by exposure of isolated islets to glipizide, which inhibits ATP-dependent $\mathrm{K}^{+}$channel activity in pancreatic B-cells, and by exposure of islets to a high extracellular $\mathrm{K}^{+}$concentration, which directly induces a depolarization of the B-cell plasma membrane.

\section{Materials and Methods}

\section{Islet preparation and incubation}

Pancreatic islets were isolated from adult male SpragueDawley rats (bred in a local colony at the Biomedical Centre, Uppsala, Sweden) by a collagenase digestion procedure (Schnell et al. 1988). The experiments were performed in accordance with principles of laboratory animal care, and the research protocol including all experimental procedures involving animals was approved by the Regional Animal Ethical Committee. Groups of 150 islets were cultured free floating for 6-7 days in $5 \mathrm{ml}$ RPMI 1640 medium (Sigma Chemical Co., St Louis, MO, USA) containing $11 \mathrm{mM}$ glucose and supplemented with $10 \% \quad(\mathrm{v} / \mathrm{v})$ fetal calf serum (Sigma Chemical Co.), $0.17 \mathrm{mM}$ sodium benzylpenicillinate and $0.17 \mathrm{mM}$ streptomycin. The islet cultures were maintained in an atmosphere of humidified air and $5 \%(\mathrm{v} / \mathrm{v})$ carbon dioxide at $37^{\circ} \mathrm{C}$. The medium was changed every second day.

Subsequent to culture, the islets were incubated at $37^{\circ} \mathrm{C}$ in a bicarbonate buffer (Krebs \& Henseleit 1932) supplemented with $10 \mathrm{mM}$ 4-(2-hydroxyethyl)piperazine-1-ethanesulphonic acid and adjusted to $\mathrm{pH}$ 7.4. Incubations were performed for $1 \mathrm{~h}$ with or without $0.3 \mathrm{mM}$ diazoxide (Sigma Chemical Co.) in the presence of $11 \mathrm{mM}$ glucose and with or without $35 \mu \mathrm{M}$ glipizide (a generous gift from Pharmacia, Uppsala, Sweden) at $5 \mathrm{mM}$ glucose. Also, isolated islets were incubated with $5 \mathrm{mM}$ glucose for $1 \mathrm{~h}$ and then for another $30 \mathrm{~min}$ in the presence or absence of $50 \mathrm{mM}$ potassium chloride at the same glucose concentration. After these incubations the islets were subjected to morphological examination, Western blot analysis, determination of GLUT2 phosphorylation or measurements of net glucose uptake or glucose oxidation in media of the same compositions.

\section{Morphological examination}

To determine GLUT2 and insulin content in islet B-cells by immunohistochemistry and to measure immunofluorescence, 150 islets from the various incubations were transferred to conical glass tubes and sedimented at 800 r.p.m. for $2 \mathrm{~min}$. The incubation medium was removed, leaving about $200 \mu \mathrm{l}$, before the islets were fixed in $8 \mathrm{ml}$ Bouin's solution and dehydrated in a graded series of ethanol. The islet pellets were embedded in paraffin or frozen in liquid nitrogen. Double immunofluoresence staining for GLUT2 and insulin was performed on $5-\mu \mathrm{m}$ thick sections. For this purpose a rabbit antibody raised against peptide 512-522 of rat GLUT2 (a generous gift from Prof. B Thorens, Lausanne, Switzerland) at a dilution of 1:200, followed by CY 3-conjugated donkey anti-rabbit IgG (Jackson Immunoresearch Laboratories, West Grove, PA, USA), and a guinea-pig anti-insulin antibody (DAKO, Glostrup, Denmark) at a dilution of 1:400 followed by FITC-conjugated rabbit anti-guinea-pig $\operatorname{IgG}$ (Jackson Immunoresearch Laboratories) were used.

Morphological analysis and measurements of the average fluorescence intensities of insulin and GLUT2 per unit islet section area were performed by a confocal microscope (Laser Scan Microscope 410; Carl Zeiss, Jena, Germany) at excitation wavelengths of 543 and $488 \mathrm{~nm}$. For each of the incubation conditions, 20-45 islets were examined in each of three experiments. To standardize the measurements of immunofluorescence, brightness and contrast were set for islets incubated without diazoxide, glipizide or $50 \mathrm{mM}$ potassium chloride, and exactly the same settings were also used for the islets exposed to the substances in each experiment.

\section{$\mathrm{K}^{+}$-stimulated insulin release and islet content of insulin}

After exposure to a high concentration of potassium chloride as described above, triplicates of fifteen islets from the control and experimental groups were transferred to $200 \mu \mathrm{l}$ redistilled water and homogenized by sonication $(20 \mathrm{kHz} ; 50 \mathrm{~W})$ for $10 \mathrm{~s}$. The incubation media were also collected. The insulin content of the islet homogenates and that of the incubation media was determined with a direct sandwich ELISA for rat insulin utilizing two different monoclonal antibodies directed against separate antigenic epitopes of the insulin molecule (Mercodia, Uppsala, Sweden). 


\section{Western blot analysis}

After exposure to $50 \mathrm{mM}$ potassium chloride, the islets were kept at $-70{ }^{\circ} \mathrm{C}$. Western blot analysis was performed as described previously (Winqvist et al. 1992). Briefly, protein from 200 islets was heated at $95^{\circ} \mathrm{C}$ for $3 \mathrm{~min}$ in a sample buffer, and then separated by SDS-PAGE on $10-15 \%(w / v)$ gradient slab gels. To secure exact alignment at the subsequent analysis, trace amounts of prestained molecular weight standards (Bio-Rad Laboratories, Hercules, CA, USA) were included in each lane. Following electrophoresis, the proteins were transferred overnight to nitrocellulose membranes using a constant current of $200 \mathrm{~mA}$. Subsequently, the membranes were cut into strips and blocked by incubation in phosphate-buffered saline containing $1 \%(\mathrm{w} / \mathrm{v})$ gelatine for $1 \mathrm{~h}$. The strips were then incubated for $2 \mathrm{~h}$ with a rabbit polyclonal antiserum raised against the peptide sequence 55-67 in the extracellular loop of GLUT2 (Nordic BioSite, Täby, Sweden) at a dilution of 1:500, or with a rabbit polyclonal anti-MHC class I antiserum (a generous gift from Prof. L Rask, Uppsala, Sweden) at a dilution of 1:500. For detection, the strips were then incubated for $1.5 \mathrm{~h}$ with an alkaline phosphatase-conjugated species-specific antiIgG antibody (Bio-Rad Laboratories) at a dilution of 1:2000. Development was performed with $p$-nitroblue tetrazolium chloride and 5-bromo-4-chloro-3-indolylphosphate toluidine salt (Bio-Rad Laboratories). The colour reaction was stopped by rinsing in water. The bands of GLUT2 and MHC class I were scanned and transformed to digital images, and then analysed with an imaging system.

\section{GLUT2 phosphorylation}

Phosphorylation of GLUT2 was examined essentially as described by Thorens et al. (1996). Duplicate sets of 500 islets were first labelled by an incubation for $2 \mathrm{~h}$ with $37 \mathrm{MBq} / \mathrm{ml}$ sodium dihydrogen $\left[{ }^{32} \mathrm{P}\right]$ phosphate (Amersham Biosciences, Little Chalfont, Bucks, UK) to give a specific radioactivity of $7.4 \mathrm{GBq} / \mathrm{mmol}$ in a medium containing $0.3 \mathrm{mM}$ diazoxide and $11 \mathrm{mM}$ glucose. Subsequently, the islets were incubated for $30 \mathrm{~min}$ in the presence or absence of $50 \mathrm{mM}$ potassium chloride. The islets were washed in ice-cold phosphate-buffered saline and then lyzed in such a solution containing 1\% (v/v) Triton X-100, $1 \mathrm{mM}$ ethylenediaminetetraacetic acid, $10 \mathrm{mM}$ sodium fluoride, $1 \mathrm{mM}$ sodium orthovanadate, $2 \mathrm{mM}$ phenylmethanesulphonyl fluoride and $0 \cdot 1 \mu \mathrm{M}$ aprotinin. After centrifugation, the lysates were incubated with rProtein A Sepharose Fast Flow (Amersham Biosciences, Uppsala, Sweden) and two rabbit antisera against peptide 512-522 (a generous gift from Prof. B Thorens) and peptide 55-67 (Nordic BioSite) of rat GLUT2. The beads were washed and the protein dissociated in a sample buffer and loaded on a $7 \cdot 5 \%(\mathrm{w} / \mathrm{v})$
SDS-polyacrylamide gel parallel to protein molecular weight markers (Amersham Biosciences). Following electrophoresis, the gels were dried and the labelled protein was visualized by autoradiography using a PosphorImager (Molecular Dynamics, Sunnyvale, CA, USA).

\section{Islet net glucose uptake}

Islet net glucose uptake was measured by a technique adapted for isolated pancreatic islets (Henquin \& Lambert 1975). The incubations were carried out in 0.4-ml polyethene test tubes containing $200 \mu \mathrm{l}$ of a mixture of dibutyl phthalate and dinonyl phthalate $(3 \cdot 3 / 1 ; \mathrm{v} / \mathrm{v})$ layered on $25 \mu \mathrm{l} 6 \mathrm{M}$ urea in water. Batches of ten islets were transferred to a 50- $\mu$ drop of incubation medium separated from the oil by an air-bubble. The medium was supplemented with $0.1 \mathrm{mM}$ sucrose as an extracellular marker. At zero time, another $50 \mu \mathrm{l}$ incubation medium were added to the drop with the islets. This medium contained $\left[6,6^{\prime}(\mathrm{n})-{ }^{3} \mathrm{H}\right]$ sucrose (Amersham Biosciences, $\mathrm{UK})$ to give a final specific radioactivity of $10 \mathrm{GBq} / \mathrm{mmol}$ and $\mathrm{D}_{-}\left[\mathrm{U}_{-}{ }^{14} \mathrm{C}\right]$ glucose (Amersham Biosciences, UK) to give a final specific radioactivity of $101 \mathrm{MBq} / \mathrm{mmol}$ at a glucose concentration of $5 \mathrm{mM}$ and $46 \mathrm{MBq} / \mathrm{mmol}$ at $11 \mathrm{mM}$ glucose. The islets were then incubated for 1,5 , 10 , or $20 \mathrm{~min}$ at $37^{\circ} \mathrm{C}$ and separated from the radioactive medium by centrifugation at $9000 \times g$ for $5 \mathrm{~min}$. The bottom of the tubes containing the islets was cut off and radioactivity was measured by liquid-scintillation counting. The discriminators of the liquid-scintillation spectrometer (Wallac 1409; PerkinElmer Life Sciences, Boston, MA, USA) were adjusted for counting less than $0 \cdot 01 \%$ of ${ }^{3} \mathrm{H}$ events in the higher energy channel. At this setting $1.5 \%$ of ${ }^{14} \mathrm{C}$ events were counted in the lower energy channel. Standard samples $(5 \mu l)$ of the incubation media were treated and counted as tissue specimens.

\section{Islet glucose oxidation}

Glucose oxidation was measured as described earlier (Borg et al. 1979). Groups of 10 islets from each experimental condition were transferred to glass vials containing $100 \mu \mathrm{l}$ incubation medium supplemented with D-[U- $\left.{ }^{14} \mathrm{C}\right]$ glucose (Amersham Biosciences, UK) to a specific radioactivity of $22 \mathrm{MBq} / \mathrm{mmol}$ at $5 \mathrm{mM}$ glucose and $10 \mathrm{MBq} / \mathrm{mmol}$ at $11 \mathrm{mM}$ glucose. Incubations were performed for $90 \mathrm{~min}$ at $37^{\circ} \mathrm{C}$. Blank corrections were based on incubations without islets.

\section{Statistical analysis}

Data are given as mean values \pm S.E.M., and statistical inferences are based on Student's $t$-test.

\section{Results}

Immunohistochemical visualization of GLUT2 showed that this protein was localized in the plasma membrane of 

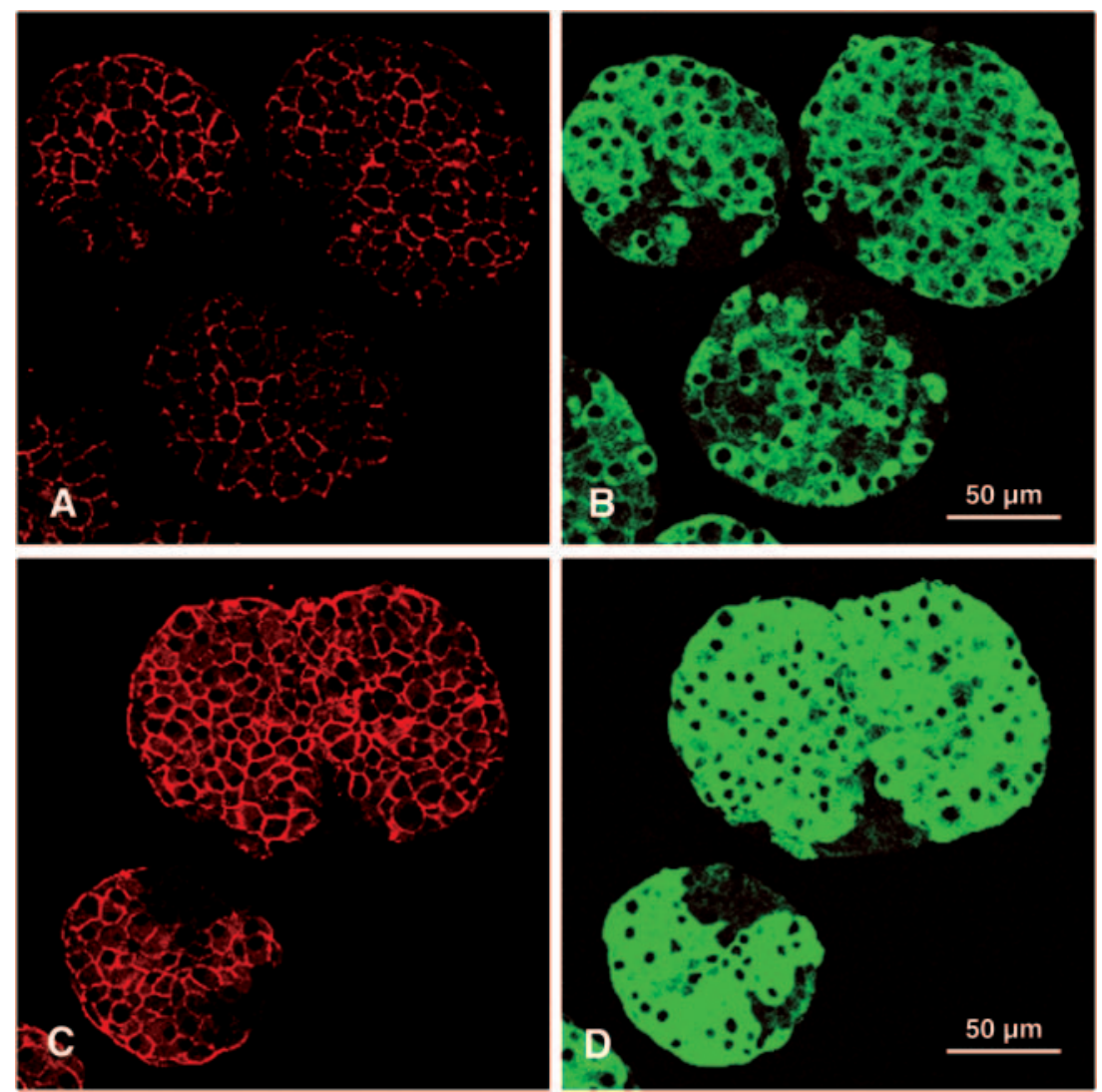

Figure 1 Double immunofluorescence staining for GLUT2 (red) and insulin (green) of rat pancreatic islets incubated with $11 \mathrm{mM}$ glucose $(A, B)$ or $11 \mathrm{mM}$ glucose plus $0.3 \mathrm{mM}$ diazoxide (C, D).

the pancreatic B-cells (Fig. 1). Insulin was, on the contrary, distributed throughout the entire B-cell cytoplasm. The fluorescence of GLUT2 and insulin was higher $(P<0 \cdot 05)$ in islets incubated with $5 \mathrm{mM}$ glucose than in islets incubated with $11 \mathrm{mM}$ glucose (Table 1). When the isolated islets were treated with $0.3 \mathrm{mM}$ diazoxide in the presence of $11 \mathrm{mM}$ glucose, both the fluorescence of GLUT2 and insulin seemed to increase in the B-cells (Fig. 1). Indeed, the measurements of fluorescence intensity revealed that GLUT2 fluorescence was $87 \%$ higher in islets exposed to diazoxide than in islets not treated with this substance (Table 1). Also, diazoxide caused an increase

Table 1 Intensity of immunofluorescence of GLUT2 and insulin in rat pancreatic islets incubated with diazoxide, glipizide or a high extracellular $\mathrm{K}^{+}$concentration. Results are given as mean values \pm S.E.M. of $58-134$ observations

Fluorescence intensity (arbitrary units)

\section{Incubation}

$11 \mathrm{mM}$ glucose

$11 \mathrm{mM}$ glucose $+0 \cdot 3 \mathrm{mM}$ diazoxide

$5 \mathrm{mM}$ glucose

$5 \mathrm{mM}$ glucose $+35 \mu \mathrm{M}$ glipizide

$5 \mathrm{mM}$ glucose

$5 \mathrm{mM}$ glucose $+50 \mathrm{mM} \mathrm{KCl}$

\begin{tabular}{lc}
\hline GLUT2 & Insulin \\
& \\
$44 \cdot 9 \pm 1 \cdot 9$ & $95 \cdot 9 \pm 3 \cdot 8$ \\
$83 \cdot 8 \pm 3 \cdot 2^{* * *}$ & $167 \cdot 2 \pm 4 \cdot 3^{* * *}$ \\
$95 \cdot 0 \pm 3 \cdot 9$ & $136 \cdot 5 \pm 5 \cdot 1$ \\
$50 \cdot 7 \pm 3 \cdot 0^{* * *}$ & $58 \cdot 6 \pm 3 \cdot 6^{* * *}$ \\
$88 \cdot 4 \pm 2 \cdot 8$ & $150 \cdot 1 \pm 3 \cdot 9$ \\
$47 \cdot 0 \pm 1 \cdot 7^{* * *}$ & $54 \cdot 0 \pm 2 \cdot 9^{* * *}$ \\
\hline
\end{tabular}

${ }^{* * *} P<0 \cdot 001$ compared with respective glucose alone group. 
in insulin fluorescence by $74 \%$. In contrast, after incubation with $35 \mu \mathrm{M}$ glipizide, the islets had a weak GLUT2 staining in the B-cell plasma membrane as well as insulin staining in the B-cell cytoplasm. The GLUT2 fluorescence intensity in the B-cells was reduced by $47 \%$, and the insulin fluorescence intensity was reduced by $57 \%$ (Table 1). Incubation of the islets with lower concentrations of diazoxide $(0.03 \mathrm{mM})$ or glipizide $(3.5 \mu \mathrm{M})$ also resulted in an enhanced and a reduced GLUT2 fluorescence respectively, but the changes in fluorescence were of a lower magnitude (data not shown). Exposure of the islets to $50 \mathrm{mM}$ potassium chloride decreased the GLUT2 fluorescence intensity by $47 \%$ and the insulin fluorescence intensity by $64 \%$ in the $\mathrm{B}$-cells (Table 1 ). In this experimental group there were, however, a few B-cells that still kept strong GLUT2 and insulin staining.

The results of the immunofluorescence measurements were confirmed by the determinations of insulin in the incubations with a high extracellular $\mathrm{K}^{+}$concentration. In the presence of $50 \mathrm{mM}$ potassium chloride at a glucose concentration of $5 \mathrm{mM}$, the islet insulin content was $204 \cdot 2 \pm 10 \cdot 4 \mathrm{ng} /$ islet $(n=3)$, whereas it was $258 \cdot 7 \pm$ $11.6 \mathrm{ng} /$ islet $(n=3)$ after incubations without addition of potassium chloride. The difference in islet insulin content was statistically significant $(P<0 \cdot 05)$. After $30 \mathrm{~min}$, the islets incubated with $50 \mathrm{mM}$ potassium chloride had released $14 \cdot 0 \pm 1 \cdot 0 \mathrm{ng}$ insulin/islet $(n=3)$ and the islets exposed to $5 \mathrm{mM}$ glucose alone had released $3 \cdot 0 \pm 0.5 \mathrm{ng}$ insulin/islet $(n=3)$, which accounted for a significant difference $(P<0 \cdot 01)$.

To determine whether the changes in immunofluorescence of GLUT2 were associated with alterations in its molecular size, the islets were incubated with $50 \mathrm{mM}$ potassium chloride and Western blot analysis was performed. A predominant band at a molecular weight of 57000 was detected both in the control islet samples and in the samples from the islets incubated with $50 \mathrm{mM}$ potassium chloride (Fig. 2). A broader weak band at a lower molecular weight resulted presumably from partial degradation of the glucose transporter during the extraction procedure. Exposure of the islets to the high extracellular $\mathrm{K}^{+}$concentration resulted, however, in a decrease by $42 \pm 7 \%(n=3)$ of the immunodetectable islet GLUT2 protein content $(P<0 \cdot 05)$, whereas the amount of the MHC class I protein $\left(M_{r} 41000\right)$, serving as an internal control, was not altered.

To determine whether the changes in immunofluorescence of GLUT2 were associated with alterations in its phosphorylation, the islets were labelled with radioactive phosphate and incubated with $50 \mathrm{mM}$ potassium chloride. Immunoprecipitates of islet lysates were then examined by electrophoresis and autoradiography (Fig. 3). A distinct labelled band corresponding to the molecular weight of the GLUT2 protein was found in the lysates from both control islets and from islets exposed to $50 \mathrm{mM}$ potassium chloride. However, the labelling of GLUT2 did not differ between the two experimental groups.

\section{GLUT2}

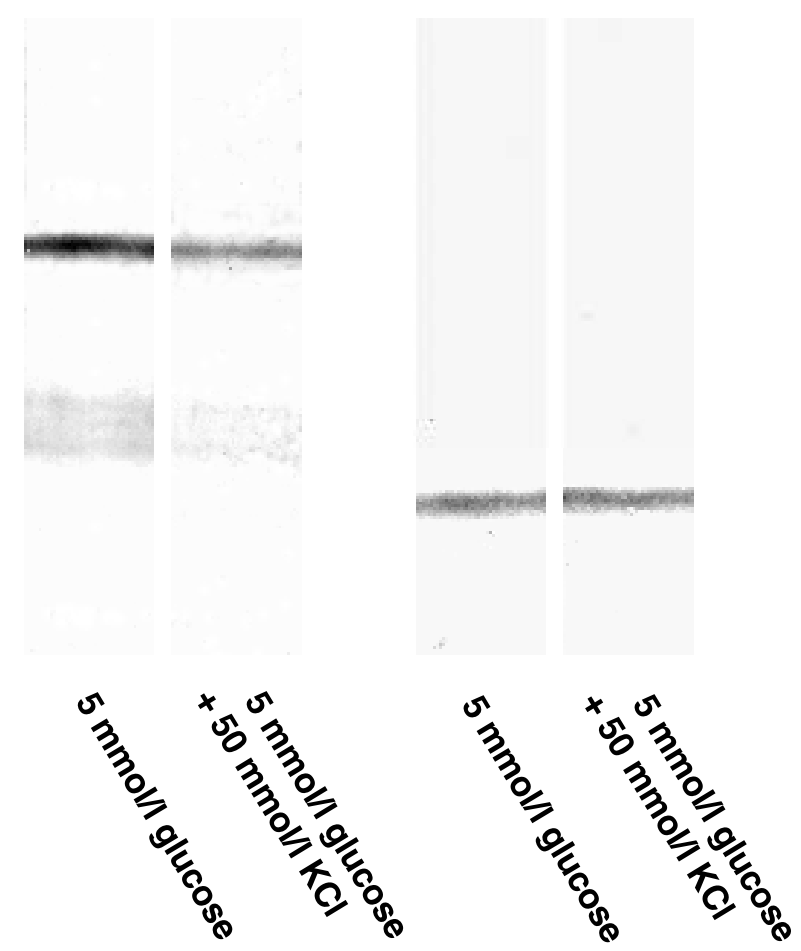

Figure 2 Western blot analysis of GLUT2 and MHC class I protein of rat pancreatic islets incubated with $5 \mathrm{mM}$ glucose or $5 \mathrm{mM}$ glucose plus $50 \mathrm{mM}$ potassium chloride. The figure is representative for three separate experiments.

The cellular net uptake of glucose was measured in islets exposed to diazoxide, glipizide or $50 \mathrm{mM}$ potassium chloride for a duration of 1, 5, 10 and 20 min. During $1 \mathrm{~min}$, the net uptake of $\mathrm{D}_{-}\left[\mathrm{U}_{-}{ }^{14} \mathrm{C}\right]$ glucose did not differ between the islets exposed to the various treatments and the controls. In the islets incubated with diazoxide, a significant increase in the net glucose uptake was found at 5 to $20 \mathrm{~min}$ (Fig. 4). However, the islets incubated with glipizide or $50 \mathrm{mM}$ potassium chloride showed a significantly decreased net glucose uptake in comparison with controls at 5 to $20 \mathrm{~min}$ (Figs 5 and 6).

In the glucose oxidation experiments, no difference in glucose oxidation rate was detected when the diazoxidetreated islets were compared with the control islets. A significantly reduced glucose oxidation rate was, however, found in the islets exposed to glipizide. The same effect was also observed in the islets exposed to $50 \mathrm{mM}$ potassium chloride (Fig. 7).

\section{Discussion}

We observed that immunostaining of GLUT2 in the pancreatic B-cell plasma membrane was markedly 

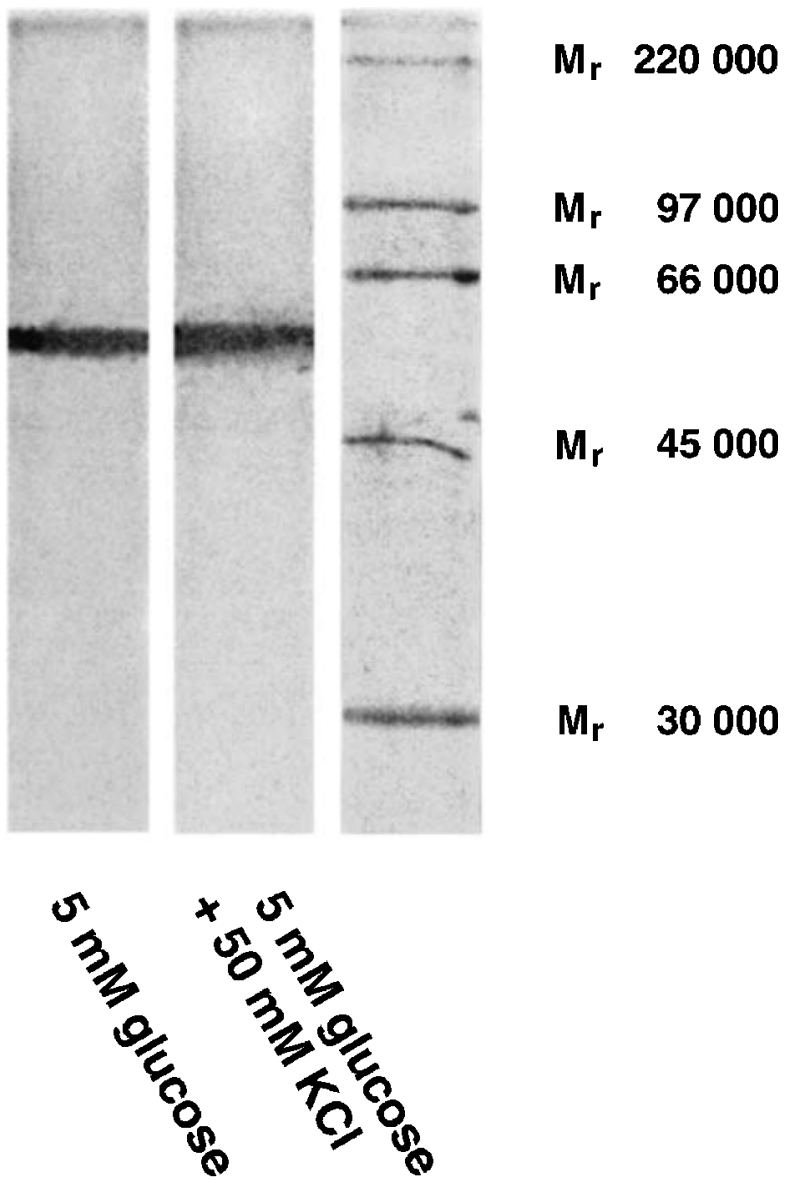

$M_{r} \quad 30000$

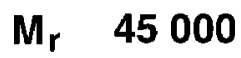

Figure 3 Phosphorylation of GLUT2 of rat pancreatic islets incubated with $5 \mathrm{mM}$ glucose or $5 \mathrm{mM}$ glucose plus $50 \mathrm{mM}$ potassium chloride.

increased by the incubation of rat islets with diazoxide, which is an opener of ATP-dependent $\mathrm{K}^{+}$channels and an inhibitor of insulin secretion (Henquin \& Meissner 1982). Conversely, a lesser amount of detectable glucose transporter in the B-cell plasma membrane was found following the stimulation of insulin secretion with the ATP-dependent $\mathrm{K}^{+}$channel blocker glipizide or by the stimulation of insulin release by direct depolarization of the plasma membrane with a high extracellular $\mathrm{K}^{+}$concentration. In parallel experiments, concordant increases and reductions in glucose net uptake were recorded. Thus, our findings suggest that the altered GLUT2 staining reflects changes of functional importance. The data also demonstrate that the protective effect of $\mathrm{K}^{+}$channel opening against streptozotocin-induced B-cell damage cannot be explained by a reduction in GLUT2, which is known to be required for streptozotocin uptake (Schnedl et al. 1994). Rather, an increased uptake of streptozotocin can be surmised following $\mathrm{K}^{+}$channel opening, indicating that the protective effect is executed via different mecha-

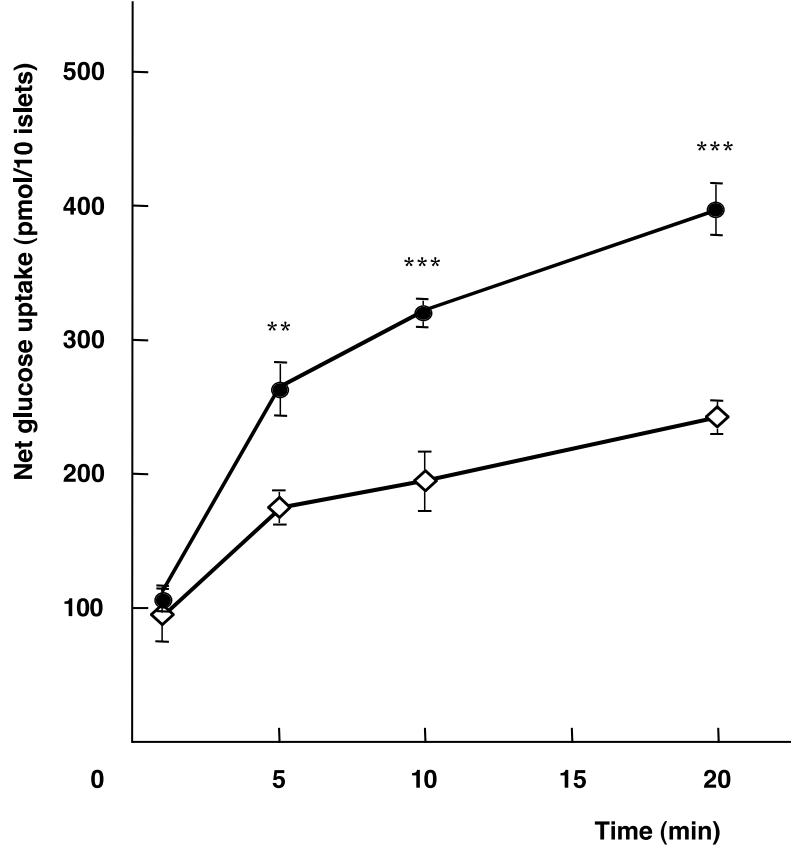

Figure 4 Net glucose uptake of rat pancreatic islets incubated with $11 \mathrm{mM}$ glucose $(\diamond)$ or $11 \mathrm{mM}$ glucose plus $0.3 \mathrm{mM}$ diazoxide ( ). Results are given as mean values \pm S.E.M. of $10-12$ observations, and differences between the two experimental groups are evaluated by Student's $t$-test. ${ }^{*} P<0 \cdot 01 ;{ }^{* * *} P<0 \cdot 001$.

nisms, perhaps linked to a hyperpolarization of the plasma membrane.

GLUT2 is the only glucose transporter normally detected in pancreatic B-cells of rodents (Thorens et al. 1988, Orci et al. 1989, Johnson et al. 1990), whereas GLUT1 seems to be the predominant transporter in human B-cells (De Vos et al. 1995, Ferrer et al. 1995). The importance of the glucose transporter for normal glucose sensing was underlined by elegant studies of GLUT2deficient mice generated by homologous recombination (Guillam et al. 2000). The transporter is synthesized by a constitutive pathway and appears to reside permanently in the plasma membrane (Thorens et al. 1993). There are no previous reports on structural changes or relocalization of the GLUT2 transporter in B-cells. The changes we detected with the use of GLUT2 antibodies occurred within 30 to $60 \mathrm{~min}$ after exposure of the islets to a high extracellular $\mathrm{K}^{+}$concentration or to the ATP-dependent $\mathrm{K}^{+}$channel agents. Since the half-life of the transporter has been estimated to be $7 \mathrm{~h}$ (Thorens et al. 1993), it seems unlikely that the changes could be explained by alterations in the synthesis or degradation of the protein. The GLUT2 immunoreactivity was largely confined to the plasma membrane. Only a weak background stain was observed intracellularly and it remained unchanged in the experiments. This indicates that the observations of the plasma membrane GLUT2 were not due to its redistribution from 


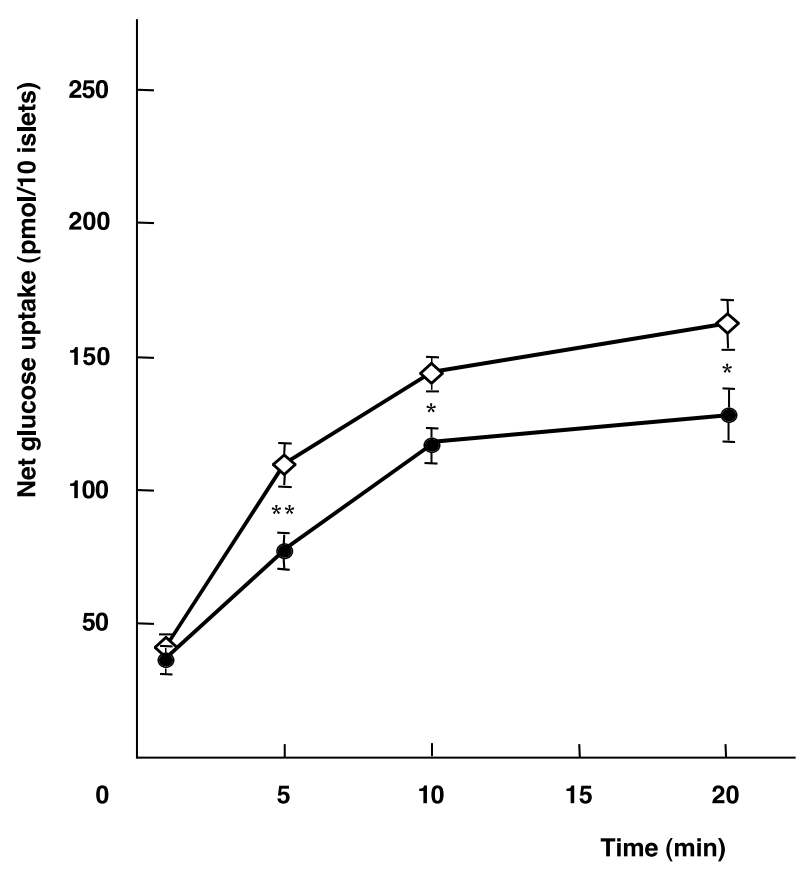

Figure 5 Net glucose uptake of rat pancreatic islets incubated with $5 \mathrm{mM}$ glucose $(\diamond)$ or $5 \mathrm{mM}$ glucose plus $35 \mu \mathrm{M}$ glipizide

(-). Results are given as mean values \pm S.E.M. of 10-12 observations, and differences between the two experimental groups are evaluated by Student's $t$-test. ${ }^{*} P<0 \cdot 05$; ${ }^{*} P<0 \cdot 01$.

intracellular compartments. The lower immunoreactivity of GLUT2 in the islets with a stimulated insulin secretion seems not to result from shedding processes, since there was no change in the molecular weight of GLUT2 in the islets incubated at a high extracellular $\mathrm{K}^{+}$concentration. Possibly, conformational changes of the transporter might occur within the B-cell plasma membrane, altering its recognition by the antibodies used. Such modification can also explain the reduction in GLUT2 detected in the Western blot experiments.

It is tempting to speculate that conformational changes in GLUT2 could reflect phosphorylation/dephosphorylation of the protein. It has been shown that GLUT2 is phosphorylated at its carboxy-terminal tail by a cAMPdependent protein kinase A after activation of adenyl cyclase by forskolin or glucagon-like peptide-1 (Thorens et al. 1996). Also, it is known that the C-terminal portion of GLUT2 is of importance for its intrinsic transport activity (Oka et al. 1990, Katagiri et al. 1992). The phosphorylation of the rat GLUT2 protein was demonstrated in cell sorter purified B-cells and was accompanied by a reduction of about $50 \%$ in the initial rate of glucose transport into the cells. Intact pancreatic islets have a higher basal level of GLUT2 phosphorylation than the cell sorter purified B-cells, and a further phosphorylation of the transporter was not demonstrated in intact islets subjected to stimuli of insulin secretion (Thorens et al. 1996).

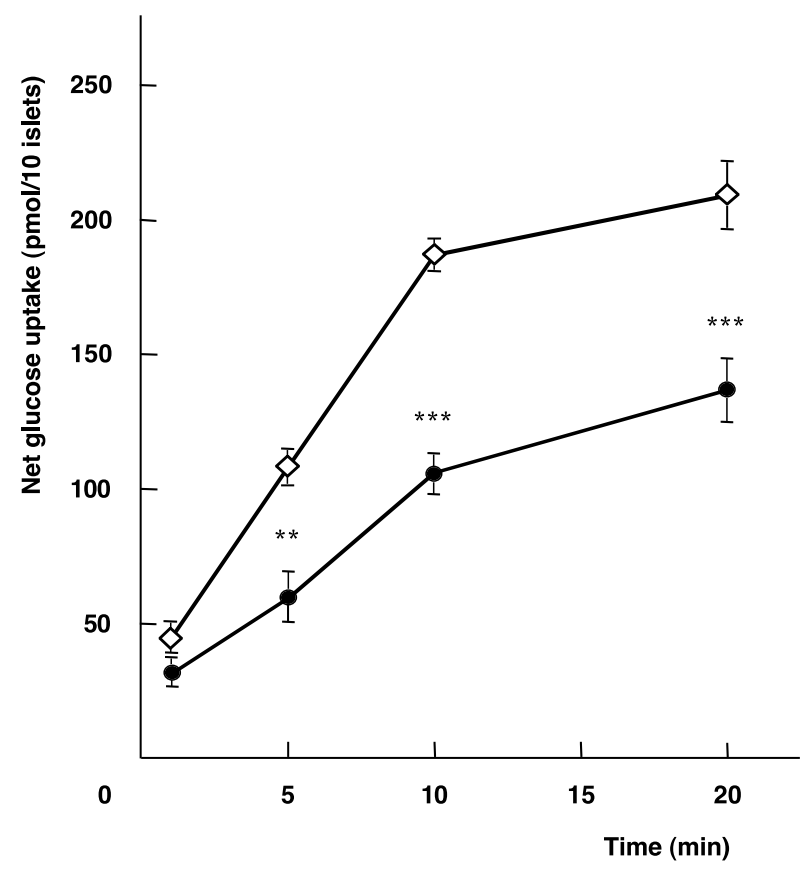

Figure 6 Net glucose uptake of rat pancreatic islets incubated with $5 \mathrm{mM}$ glucose $(\diamond)$ or $5 \mathrm{mM}$ glucose plus $50 \mathrm{mM}$ potassium chloride ( ). Results are given as mean values \pm S.E.M. of $10-12$ observations, and differences between the two experimental groups are evaluated by Student's t-test. ${ }^{* *} P<0 \cdot 01$; ${ }^{* *} P<0 \cdot 001$.

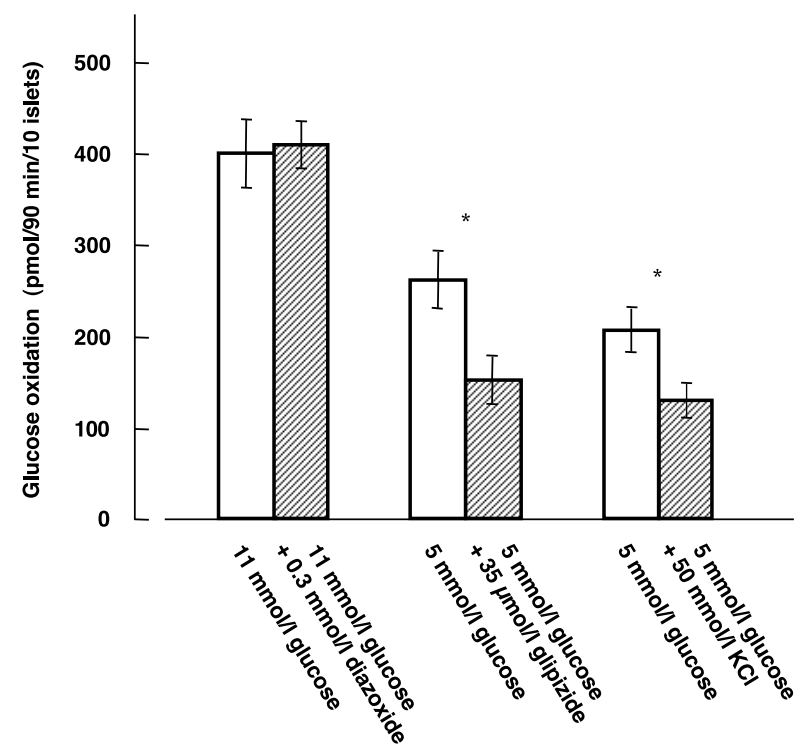

Figure 7 Glucose oxidation of rat pancreatic islets incubated with 11 or $5 \mathrm{mM}$ glucose alone (open bars) and with the addition of $0.3 \mathrm{mM}$ diazoxide, $35 \mu \mathrm{M}$ glipizide or $50 \mathrm{mM}$ potassium chloride (hatched bars). Results are given as mean values \pm S.E.M. of 8 observations, and differences compared with incubations without additions are evaluated by Student's $t$-test. ${ }^{*} P<0 \cdot 05$. 
Neither could we detect any increase in phosphorylation of GLUT2 in intact rat islets, which were pretreated with diazoxide and then exposed to a high extracellular $\mathrm{K}^{+}$ concentration stimulating insulin secretion.

It has been shown that neither diazoxide, sulphonylureas nor an extracellular $\mathrm{K}^{+}$concentration of about $50 \mathrm{mM}$ has any effect on islet production of glucosederived lactate or amino acids (Malaisse et al. 1993, 1999, Picton et al. 1998). Therefore, the present findings on net glucose uptake can be taken to reflect the B-cell rate of inward glucose transport. In the diazoxide-treated islets, the net glucose uptake was increased parallel to an enhanced GLUT2 staining in the B-cell plasma membrane, whereas the oxidation of glucose remained unchanged. The latter finding is in accordance with previous results showing no effect of diazoxide on glucose oxidation in isolated islets (Ashcroft \& Randle 1970, Bergsten et al. 1988, Malaisse et al. 1999). The increased uptake of glucose caused by diazoxide would, however, be expected to increase B-cell glucose metabolism. Probably, an unchanged glucose oxidation in spite of an increased net glucose uptake reflects a lower requirement for energy production in B-cells with inhibited exocytosis. Indeed, there is evidence that a diazoxide-dependent hyperpolarization of the B-cell plasma membrane leads to inhibition of the $\mathrm{Na}^{+} / \mathrm{K}^{+}$pump and thus a saving of energy, an increased B-cell ATP content and a negative feed-back on oxidative metabolism (Elmi et al. 2001a,b). In addition, diazoxide may also have a direct effect on the mitochondrial membrane potential resulting in restricted oxidative metabolism (Grimmsmann \& Rustenbeck 1998). Glucose may form glycogen, when not being metabolized by oxidation. Glycogen constitutes a labile pool for glucose storage, and the pancreatic B-cells have been shown to possess a great capacity for glycogen accumulation (Andersson et al. 1974, Fontela et al. 1984).

There was also a parallelism between the net glucose uptake and the GLUT2 staining in the B-cell plasma membrane in the experiments utilizing glipizide or a high extracellular $\mathrm{K}^{+}$concentration to stimulate insulin secretion. The islets showed a reduced net glucose uptake and a reduced glucose oxidation in both sets of experiments. The effects on glucose oxidation agree well with earlier findings. Thus, in studies of the insulinotrophic effects of tolbutamide it was found that glucose oxidation and other metabolic variables were often diminished (Stork et al. 1969, Hellman 1970), indicating that, contrary to the expectations at that time, a facilitated nutrient metabolism does not explain the insulinotrophic effect of the drug. Also, it has been shown that tolbutamide reduces glucose oxidation in rat islets incubated at $5.6 \mathrm{mM}$ glucose (Kawazu et al. 1980).

In conclusion, we have observed that GLUT2 and glucose uptake are modified in parallel with changes in insulin secretion. This indicates that changes in the glucose transporter could be of functional importance.

\section{Funding}

This study was supported by grants from the Swedish Research Council, the Swedish Diabetes Association, the Family Enfors Fund, and the Juvenile Diabetes Foundation International - Knut and Alice Wallenberg Foundation. The authors declare that there is no conflict of interest that would prejudice the impartiality of this scientific work.

\section{References}

Andersson A, Borglund E \& Brolin S 1974 Effects of glucose on the content of ATP and glycogen and the rate of glucose phosphorylation of isolated pancreatic islets maintained in tissue culture. Biochemical and Biophysical Research Communications $\mathbf{5 6}$ 1045-1051.

Ashcroft SJH \& Randle PJ 1970 Mechanisms in the control of insulin release by glucose and other substances. Advances in Metabolic Disorders 1 (Suppl 1) 51-57.

Atkinson MA, Maclaren NK \& Luchetta R 1990 Insulitis and diabetes in NOD mice reduced by prophylactic insulin therapy. Diabetes 39 933-937.

Bergsten P, Gylfe E, Wesslén N \& Hellman B 1988 Diazoxide unmasks glucose inhibition of insulin release by counteracting entry of $\mathrm{Ca}^{2+}$. American Journal of Physiology - Endocrinology and Metabolism 255 E422-E427.

Björk E, Kämpe O, Andersson A \& Karlsson FA 1992 Expression of the $64 \mathrm{kDa}$ /glutamic acid decarboxylase rat islet cell autoantigen is influenced by the rate of insulin secretion. Diabetologia 32 490-493.

Björk E, Berne C, Kämpe O, Wibell L, Oskarsson P \& Karlsson FA 1996 Diazoxide treatment at onset preserves residual insulin secretion in adults with autoimmune diabetes. Diabetes $\mathbf{4 5}$ 1427-1430.

Borg LAH, Eide SJ, Andersson A \& Hellerström C 1979 Effects in vitro of alloxan on the glucose metabolism of mouse pancreatic B-cells. Biochemical Journal 182 797-802.

De Vos A, Heimberg H, Quartier E, Huypens P, Bouwens L, Pipeleers D \& Schuit F 1995 Human and rat beta cells differ in glucose transporter but not in glucokinase gene expression. Journal of Clinical Investigation 96 2489-2495.

Eizirik DL, Strandell E \& Sandler S 1988 Culture of mouse pancreatic islets in different glucose concentrations modifies the B cell sensitivity to streptozotocin. Diabetologia 31 168-174.

Elmi A, Idahl L-Å \& Sehlin J 2001a Modulation of beta-cell ouabain-sensitive ${ }^{86} \mathrm{Rb}^{+}$influx $\left(\mathrm{Na}^{+} / \mathrm{K}^{+}\right.$pump) by $\mathrm{D}$-glucose, glibenclamide or diazoxide. International Journal of Experimental Diabetes Research 1 265-274.

Elmi A, Idahl L-A \& Sehlin J $2001 b$ Modulation of islet ATP content by inhibition or stimulation of the $\mathrm{Na}^{+} / \mathrm{K}^{+}$pump. European Journal of Pharmacology 426 139-143.

Ferrer J, Benito C \& Gomis R 1995 Pancreatic islet GLUT2 glucose transporter mRNA and protein expression in humans with and without NIDDM. Diabetes 44 1369-1374.

Fontela T, Garcia-Hermida O, Garcia-Fernández MC \& Gómez-Acebo J 1984 Incorporation of $\left[\mathrm{U}_{-}{ }^{14} \mathrm{C}\right]$ glucose into glycogen in normal rat pancreatic islets. Revista Española de Fisiologia $4077-81$

Gotfredsen CF, Buschard K \& Frandsen EK 1985 Reduction of diabetes incidence of BB Wistar rats by early prophylactic insulin treatment of diabetes-prone animals. Diabetologia 28 933-935.

Grimmsmann T \& Rustenbeck I 1998 Direct effects of diazoxide on mitochondria in pancreatic B-cells and on isolated liver mitochondria. British Journal of Pharmacology 123 781-788.

Guillam M-T, Dupraz P \& Thorens B 2000 Glucose uptake, utilization, and signaling in GLUT2-null islets. Diabetes $\mathbf{4 9}$ 1485-1491. 
Hagopian WA, Karlsen AE, Petersen JS, Teague J, Gervassi A, Jiang J, Fujimoto W \& Lernmark Å 1993 Regulation of glutamic acid decarboxylase diabetes autoantigen expression in highly purified isolated islets from Macaca nemestrina. Endocrinology 132 2674-2681.

Hellman B 1970 Methodological approaches to studies on the pancreatic islets. Diabetologia 6 110-120.

Henquin J-C \& Lambert AE 1975 Cobalt inhibition of insulin secretion and calcium uptake by isolated rat islets. American Journal of Physiology 228 1669-1677.

Henquin J-C \& Meissner HP 1982 Opposite effects of tolbutamide and diazoxide on ${ }^{86} \mathrm{Rb}^{+}$fluxes and membrane potential in pancreatic B cells. Biochemical Pharmacology 31 1407-1415.

Hiramatsu S, Höög A, Möller C \& Grill V 2000 Treatment with diazoxide causes prolonged improvement of $\beta$-cell function in rat islets transplanted to a diabetic environment. Metabolism: Clinical and Experimental 49 657-661.

Johnson JH, Newgard CB, Milburn JL, Lodish HF \& Thorens B 1990 The high $K_{\mathrm{m}}$ glucose transporter of islets of Langerhans is functionally similar to the low affinity transporter of liver and has an identical primary sequence. Journal of Biological Chemistry 265 6548-6551.

Kämpe O, Andersson A, Björk E, Hallberg A \& Karlsson FA 1989 High-glucose stimulation of $64000-\mathrm{M}_{\mathrm{r}}$ islet cell autoantigen expression. Diabetes 38 1326-1328.

Karlsson FA \& Björk E 1997 Beta-cell rest: a strategy for the prevention of autoimmune diabetes. Autoimmunity 26 117-122.

Katagiri H, Asano T, Ishihara H, Tsukuda K, Lin J-L, Inukai K, Kikuchi M, Yazaki Y \& Oka Y 1992 Replacement of intracellular C-terminal domain of GLUT1 glucose transporter with that of GLUT2 increases $\mathrm{V}_{\max }$ and $K_{\mathrm{m}}$ of transport activity. Journal of Biological Chemistry 267 22550-22555.

Kawazu S, Sener A, Couturier E \& Malaisse WJ 1980 Metabolic, cationic and secretory effects of hypoglycemic sulfonylureas in pancreatic islets. Naunyn-Schmiedeberg's Archives of Pharmacology 312 277-283.

Kolb H 1987 Mouse models of insulin dependent diabetes: low-dose streptozotocin-induced diabetes and nonobese diabetic (NOD) mice. Diabetes/Metabolism Reviews 3 751-778.

Krebs HA \& Henseleit K 1932 Untersuchungen über die Harnstoffbildung im Tierkörper. Hoppe-Seyler's Zeitschrift für Physiologische Chemie 210 33-66.

Kullin M, Li Z, Hansen JB, Björk E, Sandler S \& Karlsson FA 2000 $\mathrm{K}_{\mathrm{ATP}}$-channel openers protect rat islets against the toxic effect of streptozotocin. Diabetes 49 1131-1136.

Malaisse WJ, Lebrun P \& Sener A 1993 Modulation of the insulinotropic action of glibenclamide and glimepiride by nutrient secretagogues in pancreatic islets from normoglycemic and hyperglycemic rats. Biochemical Pharmacology 45 1845-1849.
Malaisse WJ, Picton S, Malaisse-Lagae F \& Sener A 1999 Effects of high extracellular $\mathrm{K}^{+}$concentrations, diazoxide and/or $\mathrm{Ca}^{2+}$ deprivation upon $\mathrm{D}$-glucose metabolism in pancreatic islets. Biochimica et Biophysica Acta 1451 255-262.

Oka Y, Asano T, Shibasaki Y, Lin J-L, Tsukuda K, Katagiri H, Akanuma Y \& Takaku F 1990 C-terminal truncated glucose transporter is locked into an inward-facing form without transport activity. Nature 345 550-553.

Orci L, Thorens B, Ravazzola M \& Lodish HF 1989 Localization of the pancreatic beta cell glucose transporter to specific plasma membrane domains. Science 245 295-297.

Palmer JP, Helqvist S, Spinas GA, Mølvig J, Mandrup-Poulsen T, Andersen HU \& Nerup J 1989 Interaction of $\beta$-cell activity and IL-1 concentration and exposure time in isolated rat islets of Langerhans. Diabetes 38 1211-1216.

Picton S, Malaisse-Lagae F \& Malaisse WJ 1998 Effects of gliquidone on D-glucose metabolism in rat pancreatic islets depend on hexose concentration. Research Communications in Molecular Pathology and Pharmacology 102 99-112.

Schnedl WJ, Ferber S, Johnson JH \& Newgard CB 1994 STZ transport and cytotoxicity. Specific enhancement in GLUT2-expressing cells. Diabetes 43 1326-1333.

Schnell AH, Swenne I \& Borg LAH 1988 Lysosomes and pancreatic islet function. A quantitative estimation of crinophagy in the mouse pancreatic B-cell. Cell and Tissue Research 252 9-15.

Stork H, Schmidt FH, Westman S \& Hellerström C 1969 Action of some hypoglycaemic sulphonylureas on the oxygen consumption of isolated pancreatic islets of mice. Diabetologia 5 279-283.

Thorens B, Sarkar HK, Kaback HR \& Lodish HF 1988 Cloning and functional expression in bacteria of a novel glucose transporter present in liver, intestine, kidney and $\beta$-pancreatic islet cells. Cell 55 281-290.

Thorens B, Gérard N \& Dériaz N 1993 GLUT2 surface expression and intracellular transport via the constitutive pathway in pancreatic $\beta$ cells and insulinoma: evidence for a block in trans-Golgi network exit by brefeldin A. Journal of Cell Biology 123 1687-1694.

Thorens B, Dériaz N, Bosco D, DeVos A, Pipeleers D, Schuit F, Meda P \& Porret A 1996 Protein kinase A-dependent phosphorylation of GLUT2 in pancreatic $\beta$ cells. Journal of Biological Chemistry 271 8075-8081.

Winqvist O, Karlsson FA \& Kämpe O 1992 21-Hydroxylase, a major autoantigen in idiopathic Addison's disease. Lancet 339 1559-1562.

Yki-Järvinen H 1992 Glucose toxicity. Endocrine Reviews 13 415-431.

Received in final form 7 February 2005

Accepted 18 February 2005

Made available online as an

Accepted Preprint 24 February 2005 